\title{
Familial Neonatal Hypoproteinaemia with Exudative Enteropathy and Intestinal Lymphangiectasis
}

\author{
A. M. PARFITT* \\ From the Medical Unit, University College Hospital, London
}

Patients with hypoproteinaemia and oedema are usually found to have cirrhosis of the liver or the nephrotic syndrome. When these and other less common conditions are excluded there remains a group of patients labelled 'idiopathic hypoprcteinaemia'. Increased katabolism of albumin in these cases was first demonstrated by balance studies following intravenous albumin (Albright, Bartter, and Forbes, 1949) and by isotope studies using ${ }^{35}$ Slabelled methionine (Kinsell, Margen, Tarver, Frantz, Flanagan, Hutchin, Michaels, and McCallie, 1950). Demonstration of the gastro-intestinal tract as a site of increased katabolism of albumin was first made in a patient with Menetrier's disease, or giant rugal hypertrophy of the stomach (Citrin, Sterling, and Halsted, 1957). Following the introduction of 131I-labelled polyvinyl pyrrolidone (PVP) by Gordon (1959), and with the development of a more satisfactory technique using ${ }^{51} \mathrm{Cr}$-labelled albumin (Waldmann, 1961), it has become apparent that almost all patients with idiopathic hypoproteinaemia have increased loss of protein into the gastrointestinal tract. These developments have been reviewed by Schwartz and Jarnum (1959), and by O'Meallie (1963).

When first recognized this situation was called 'exudative enteropathy' (Gordon, 1959), but at present the usual term is 'protein losing gastroenteropathy' (Lancet, 1959) or just 'protein-losing enteropathy' (PLE). This term is in some danger of acquiring the same type of ambiguity as 'steatorrhoea' (Parfitt, 1965). It should simply mean an increased leak of protein into the gut demonstrated by one of the above-mentioned techniques, and as such it is, like steatorrhoea, a manifestation of many different diseases. Unfortunately, there is a tendency to use the term as if it were the name of a specific entity.

PLE may occur without any demonstrable

\footnotetext{
Received June 3, 1965.

* Present address: Medical Professorial Unit, University of Queensland, Brisbane Hospital, Herston, Brisbane, Australia.
}

abnormality of the small bowel wall (Donaldson and Holt, 1963), but more often it is found as a complication of one of a wide variety of intestinal diseases (Dawson, Williams, and Williams, 1961; O'Meallie, 1963). Although patients with idiopathic hypoproteinaemia and PLE may have no overt evidence of intestinal disease, it has recently been shown that many of them have a structural abnormality of the small bowel wall, most easily demonstrated by electron microscopy. This is characterized chiefly by dilatation of small lymphatics and has been termed intestinal lymphangiectasis (Waldmann, Steinfeld, Dutcher, Davidson, and Gordon, 1961).

In 1953, Bound and Hackett published a detailed study of a case of neonatal hypoproteinaemia with oedema. We have recently had the opportunity of re-investigating their patient in the light of the advances just briefly recounted, and also of studying for the first time another sib from the same family. Both the patient and his symptom-free sister have been found to have PLE. The PVP studies were carried out by the method of Dawson et al. (1961), in which paper our propositus appeared as Case 16.

\section{Case Reports}

The Family. The parents are unrelated, and neither they nor any of their relatives have shown any features of the disease which has affected 3 of their 5 children (see Fig. 1 and Table I).

The available data in the first sib (Case 1), and a detailed account of the early history of the fourth sib (Case 2), are given in the paper of Bound and Hackett (1953), and will only be briefly recapitulated here.

Case 1. R.B., a girl born in June 1944, had swelling of both feet at birth. She rapidly developed generalized anasarca, and had repeated severe infections culminating in a staphylococcal septicaemia from which she died at the age of 6 months. The total serum protein shortly before death was $3.4 \mathrm{~g}$. $/ 100 \mathrm{ml}$.

Case 2. D.B., a boy born in August 1950, had swelling of both feet at birth. He was admitted to hospital at the age of 1 month with generalized oedema 
TABLE I

Results of Protein Determinations in Normal Members of the Family

\begin{tabular}{|c|c|c|c|c|c|}
\hline & & Father & Mother & Second Sib & Third Sib \\
\hline Total protein $(\mathrm{g} . / 100 \mathrm{ml}).(1952)$ & . & $7 \cdot 6$ & $6 \cdot 8$ & $6 \cdot 7$ & $6 \cdot 4$ \\
\hline Total protein $(\mathrm{g} . / 100 \mathrm{ml}).(1962)$ & . & $6 \cdot 9$ & $6 \cdot 4$ & $7 \cdot 0$ & $6 \cdot 9$ \\
\hline Electrophoretic strip (1962) & .. & Normal & Normal & Normal & Normal \\
\hline
\end{tabular}

and ascites. The serum albumin was $2.5 \mathrm{~g} . / 100 \mathrm{ml}$., and globulin $1.5 \mathrm{~g} . / 100 \mathrm{ml}$. Dietary, renal, and hepatic causes of hypoproteinaemia were excluded. There was also a moderate aminoaciduria with a high serum $\alpha$-amino nitrogen. The patient had a good diuresis after intravenous plasma, but the effect was only temporary. A series of staphylococcal infections occurred including an abscess at the site of the intravenous infusion, purulent arthritis of the right knee, and osteomyelitis of the right humerus, left tibia, and both femora. Although the serum $\gamma$-globulin was only $0.1 \mathrm{~g} . / 100 \mathrm{ml}$., the infections were ultimately overcome by appropriate antibiotic therapy. With each bout of infection, both the oedema and the aminoaciduria increased, though there was no unequivocal relationship with changes in the serum proteins. At 6 months he was weaned to a cerealcontaining diet. By 21 months there had been a gradual progressive improvement with only slight residual oedema of the feet; the aminoaciduria had disappeared. Serum electrophoresis was first done at this time and confirmed the low albumin and almost total absence of $\gamma$-globulin. The total serum protein was $3.6 \mathrm{~g} . / 100 \mathrm{ml}$.

The published case record stopped at this point, but follow-up continued at the same hospital. In January 1954, $\gamma$-globulin was detected by electrophoresis for the first time. In July 1954, the patient was well, with serum albumin $3 \cdot 2 \mathrm{~g} . / 100 \mathrm{ml}$. and globulin $3 \cdot 6 \mathrm{~g} . / 100 \mathrm{ml}$. In July 1957, he was still well and free of oedema, and had been so except for occasional very slight ankle oedema for over five years; the serum albumin was $3.2 \mathrm{~g} . / 100 \mathrm{ml}$. and globulin $2 \cdot 7 \mathrm{~g} . / 100 \mathrm{ml}$.

In October 1960, he noticed headache, tiredness, nausea, and vomiting. After one week, swelling of the feet and abdomen rapidly developed, and he was admitted to King Edward VII Hospital, Windsor. He had oedema of both legs, ascites, and bilateral basal crepitations, with a blood pressure of $105 / 60 \mathrm{~mm}$. Hg. Investigations showed serum albumin $2.5 \mathrm{~g} . / 100 \mathrm{ml}$., globulin 1.0 g. $/ 100 \mathrm{ml}$., electrophoretic strip-low albumin and $\gamma$-globulin, urea $15 \mathrm{mg}$. $/ 100 \mathrm{ml}$., bilirubin $0.2 \mathrm{mg} . / 100$ $\mathrm{ml}$., and thymol turbidity 1 unit. While in hospital, he developed diarrhoea and fever for four days with a white blood count of $14,700 /$ c.mm. with $76 \%$ polymorphs. He was referred to University College Hospital for further study and admitted there on November 21, 1960.

On examination, he was normally developed and proportioned with height $4 \mathrm{ft}$. $6 \frac{1}{2}$ in. $(138 \mathrm{~cm}$.) (just below 50 th percentile), and weight $36.6 \mathrm{~kg}$. (above 50 th percentile). There was pitting oedema of both legs up to the knees, and ascites (abdominal girth 33 in. $(83 \mathrm{~cm}$.)). There was a soft aortic systolic murmur and a physiological third heart sound; the blood pressure was 100/50 $\mathrm{mm}$. Hg. The angles of the mouth were cracked and the tongue was red and sore.

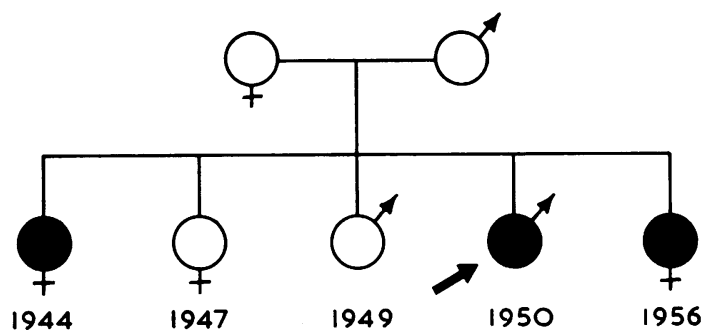

FIG. 1.-Family tree, showing years of birth.

The serum albumin was $1.8 \mathrm{~g} . / 100 \mathrm{ml}$. and globulin $2.3 \mathrm{~g} . / 100 \mathrm{ml}$; electrophoresis showed a low albumin and $\gamma$-globulin, with an increased $\alpha_{2}$ globulin. The critical investigations, demonstrating increased permeability of the gut wall to macromolecules, steatorrhoea, and abnormal histology of the small intestine wall, are summarized in Table II. The biopsy appearance (Fig. 2) bore some resemblance to that of coeliac disease, in that the villi were short and in places non-existent, but there was greater infiltration with chronic inflammatory cells, the surface epithelium was cuboidal with irregular nuclei, and the glands and crypts of Lieberkuhn were dilated with bluish grey material. Despite the villous atrophy, Dr. Shiner considered that the appearances were not those of coeliac disease. The barium meal (Fig. 3) showed evidence of mucosal thickening in the small intestine and abnormal flocculation of the contrast medium. Results of other investigations were: serum sodium 137 , potassium $4 \cdot 0$, chloride 109 , and bicarbonate $26 \mathrm{mEq} /$ litre, urea $17 \mathrm{mg}$. $/ 100 \mathrm{ml}$., bilirubin $0.2 \mathrm{mg}$./ $100 \mathrm{ml}$., liver flocculation tests negative, and glutamic oxaloacetic transaminase 14 Karmen units, cholesterol $158 \mathrm{mg}$. $/ 100 \mathrm{ml}$., tests for urine protein and amino acids negative. Because of the early history, precipitation of oedema by infection was considered; the white blood count was now $11,600 /$ c.mm., with $78 \%$ polymorphs and sedimentation rate (Westergren) $4 \mathrm{~mm}$. $/ \mathrm{hr}$. The urine contained no pus cells and was sterile, and stool cultures 
TABLE II

Results of Critical Investigations

\begin{tabular}{|c|c|c|c|c|c|c|}
\hline Patient & Date & $\frac{\mathrm{TP}}{(\mathrm{g} . / 100 \mathrm{ml} .)}$ & $\begin{array}{c}\text { PVP* } \\
(\% / 0)\end{array}$ & Faecal Fat & Barium Meal & Intestinal Biopsy \\
\hline D.B. & December 1960 & $4 \cdot 1$ & $5 \cdot 4$ & $19.9 \mathrm{~g} . / \mathrm{day}$ & $\begin{array}{l}\text { Course, thick } \\
\text { mucosal rugae }\end{array}$ & $\begin{array}{l}\text { a) Villous atrophy } \\
\text { b) Dilated glands and } \\
\text { crypts of } \\
\text { Lieberkuhn }\end{array}$ \\
\hline D.B. & February 1962 & $5 \cdot 3$ & $1 \cdot 0$ & $3 \cdot 1 \mathrm{~g} \cdot /$ day & $\begin{array}{l}\text { Reversion towards } \\
\text { normal }\end{array}$ & $\begin{array}{l}\text { No significant change } \\
\text { dilated lymphatics } \\
\text { on electron } \\
\text { microscopy }\end{array}$ \\
\hline G.B. & February 1962 & $4 \cdot 4$ & $2 \cdot 1$ & $1 \cdot 8 \mathrm{~g} \cdot /$ day & $\begin{array}{l}\text { Coarse, thick } \\
\text { mucosal rugae }\end{array}$ & Not performed \\
\hline
\end{tabular}

$\star$ Normal range: up to $1.6 \%$.

did not show any significant growth; however, an anterior nasal swab grew Staphylococcus pyogenes. Because of the steatorrhoea with soreness of tongue and mouth, further tests for malabsorption were done. The serum calcium was $8.2 \mathrm{mg} . / 100 \mathrm{ml}$. (normal for the plasma protein level), phosphorus $3.6 \mathrm{mg} . / 100 \mathrm{ml}$, alkaline phosphatase 9.3 King-Armstrong units, and 24-hour urine calcium $58 \mathrm{mg}$. A glucose tolerance test showed fasting level $80 \mathrm{mg} . / 100 \mathrm{ml}$., rising to $180 \mathrm{mg} . / 100 \mathrm{ml}$.: xylose absorption test showed excretion of $4.9 \mathrm{~g}$. in five hours after $25 \mathrm{~g}$. by mouth. The haemoglobin was $15 \cdot 1 \mathrm{~g}$./ $100 \mathrm{ml}$. Excretion of formiminoglutamic acid after histidine load was normal (the patient was Case 2 in the paper of Knowles (1962)). A sample of sweat obtained by iontophoresis contained sodium 35 and chloride 12 $\mathrm{mEq} /$ litre. Paracentesis showed the ascitic fluid to be milky; it had a cholesterol content of $59 \mathrm{mg} . / 100 \mathrm{ml}$. and did not contain chyle on microscopical examination. Further studies of some individual serum proteins were carried out; the titres of blood group substances were anti A 1/128, anti B 1/128. Serum $\gamma$-globulin by immunoelectrophoresis was $640 \mathrm{mg} . / 100 \mathrm{ml}$., and $\gamma$-macroglobulin ( $\left.{ }^{\mathrm{B}} 2 \mathrm{M}, \iota\right) 100 \%$ of standard normal serum.

Initially the patient continued to have slight nausea, and occasional epigastric discomfort, but these symptoms soon abated. The oedema and ascites began to diminish about a week after admission and within a further three weeks had disappeared entirely. An attempt to obtain further ascitic fluid for more detailed analysis was unsuccessful. This resolution of the

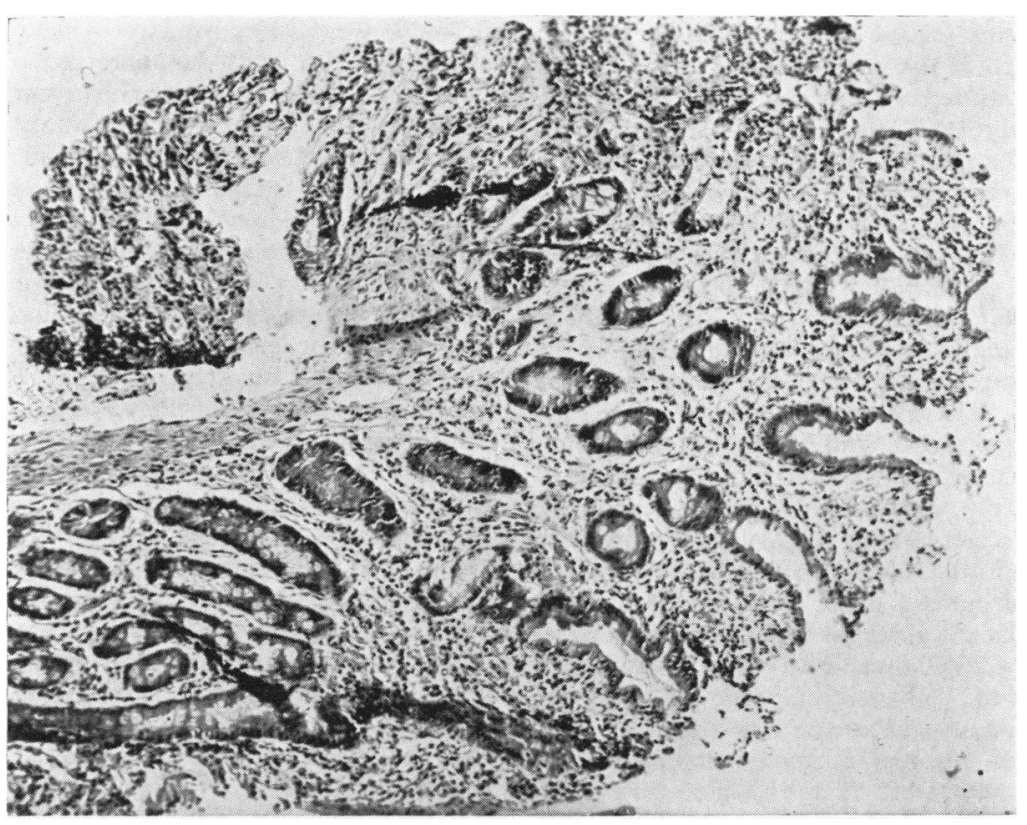

FIG. 2.-Jejunal biopsy before gluten-free diet. $(\times 84)$. Note flattened villi. 


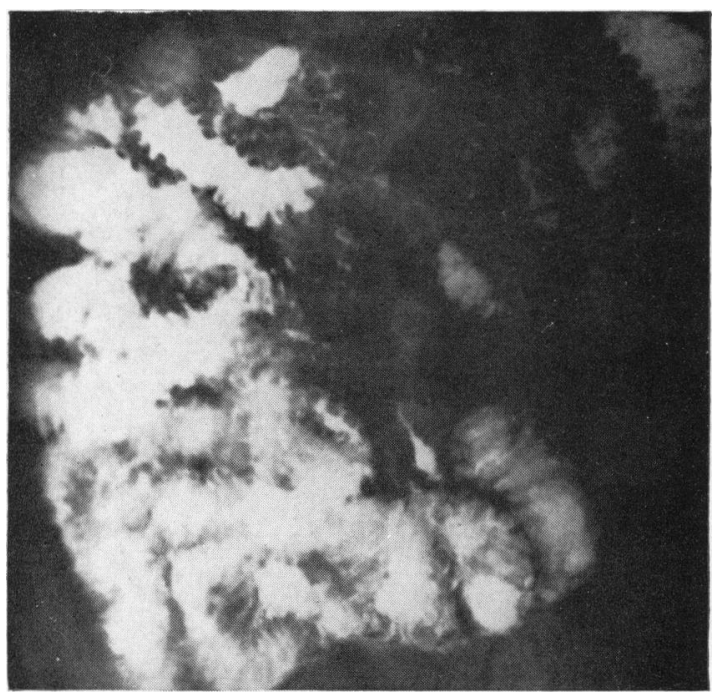

FIG. 3.-Barium meal before gluten-free diet. Note mucssal thickening and abnormal flocculation of barium.

oedema was not accompanied by any significant change in total serum protein concentration, judged by serial measurement of specific gravity, which fluctuated between 1018 and 1022. Since the apparent specific gravity (and hence the total protein concentration) can be increased by venous occlusion, and venepuncture was very difficult in this patient, small changes in these measurements have little significance. A further fat balance now showed faecal fat $13.6 \mathrm{~g}$./day with absorption $85 \%$. The intestinal biopsy appearance was not typical of coeliac disease, but in view of the villous atrophy, the steatorrhoea, and the glossitis and stomatitis, it was decided to observe the effect of a gluten-free diet which was begun on January 15, 1961. The patient was seen at regular intervals for the next year. He remained completely free of oedema and continued to grow along the same percentile lines for both height and weight. In May 1961, he had a recurrence of nausea, anorexia, vomiting, and abdominal pain for a few days, but did not develop oedema. Apart from this he remained completely symptom free. The total serum protein varied between $5 \cdot 7$ and $6 \cdot 3 \mathrm{~g} . / \mathrm{ml}$., and plasma specific gravity varied between 1021 and 1023; both of these measurements were higher than at the height of the oedema and ascites.

In order to investigate more closely the effect of the gluten-free diet the patient was admitted to the Metabolic Ward on January 28, 1962 . He was symptom free and there were no abnormal physical signs; with height $4 \mathrm{ft} .9 \frac{1}{4}$ in. ( $145 \mathrm{~cm}$.) (just below 50th percentile) and weight $37.8 \mathrm{~kg}$. (above 50th percentile). The total serum protein was now $5.5 \mathrm{~g} . / 100 \mathrm{ml}$., with plasma specific gravity 1024. A further specimen taken without venous occlusion was also examined, with results of $5.3 \mathrm{~g} . / 100 \mathrm{ml}$. and 1023 , respectively.

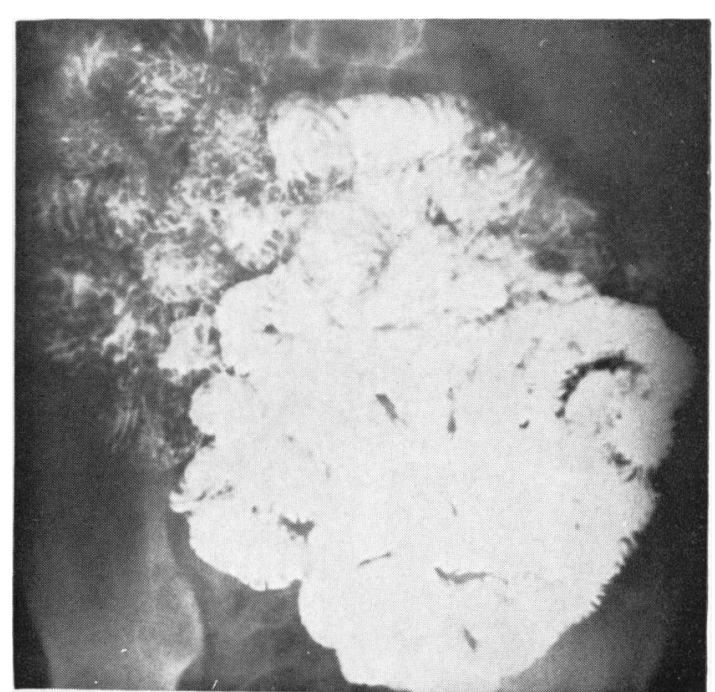

FIG. 4.-Barium meal while on gluten-free diet, showing improvement.

Electrophoresis showed a slight reduction in albumin and $\gamma$-globulin. The critical investigations were repeated and the results are summarized in Table II. They demonstrated the remarkable findings that the increased permeability and the steatorrhoea had disappeared, and the barium meal (Fig. 4) had returned to normal, though the biopsy appearances (Fig. 5a and b) were unchanged. The histological preparations were technically more satisfactory and Dr. Shiner felt even more confident that the appearances were not those of coeliac disease. Results of other investigations were: sodium 141, potassium $4.2 \mathrm{mEq} /$ litre, urea $19 \mathrm{mg} . / 100 \mathrm{ml}$., haemoglobin $14.9 \mathrm{~g} . / \mathrm{ml}$., calcium $9.0 \mathrm{mg} . / 100 \mathrm{ml}$., phosphorus $4.8 \mathrm{mg} . / 100 \mathrm{ml}$., and alkaline phosphatase $15 \mathrm{King}-$ Armstrong units; duodenal juice obtained at the time of intestinal biopsy had a $p \mathrm{H}$ of $7 \cdot 0$ and normal tryptic activity.

To determine whether the remarkable improvement was a consequence of the gluten-free diet, it was decided to reintroduce gluten into the diet under balance control. After a 5-day period of equilibration on a constant (gluten-free) diet, urine (in 3-day periods) and stools (in 6-day periods) were collected and analysed for calcium, phosphorus, and nitrogen, and stools also for fat. The results are shown in Fig. 6 . The patient was in positive balance for calcium, phosphorus, and nitrogen to a degree consistent with normal growth. The faecal nitrogen excretion was slightly increased, but otherwise the results were normal. After two 6-day periods, pure gluten $5 \mathrm{~g}$. four times daily was given by mouth. This produced no clinical effect, and no change in any of the balances; the extra dietary nitrogen in the gluten was almost exactly accounted for by the increase in urine nitrogen excretion. The small rise in faecal fat was not considered significant. 


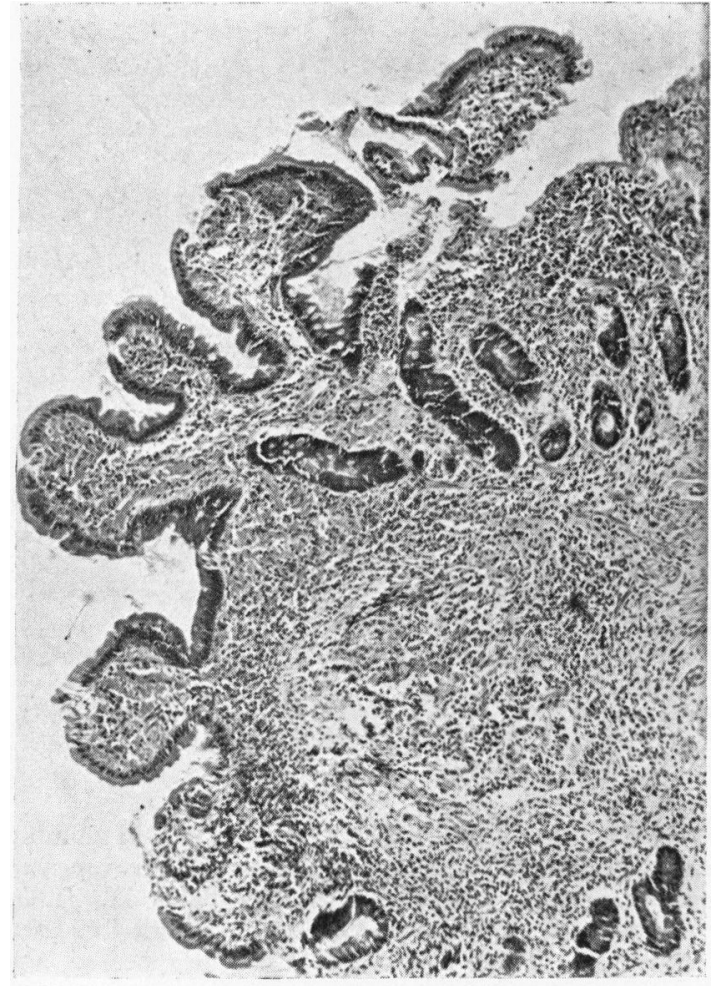

(a)
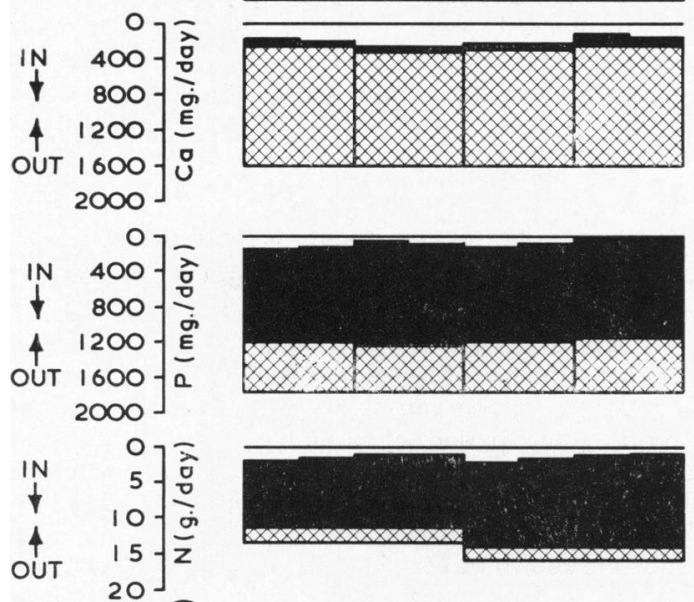

$\left.\begin{array}{l}4 \\ 3 \\ 2 \\ 1 \\ 0\end{array}\right]-\frac{\frac{\sigma}{\sigma}}{\frac{0}{\square}}$

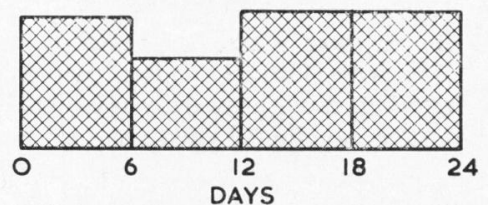

FIG. 6.-Metabolic balance chart showing lack of effect of reintroduction of gluten.

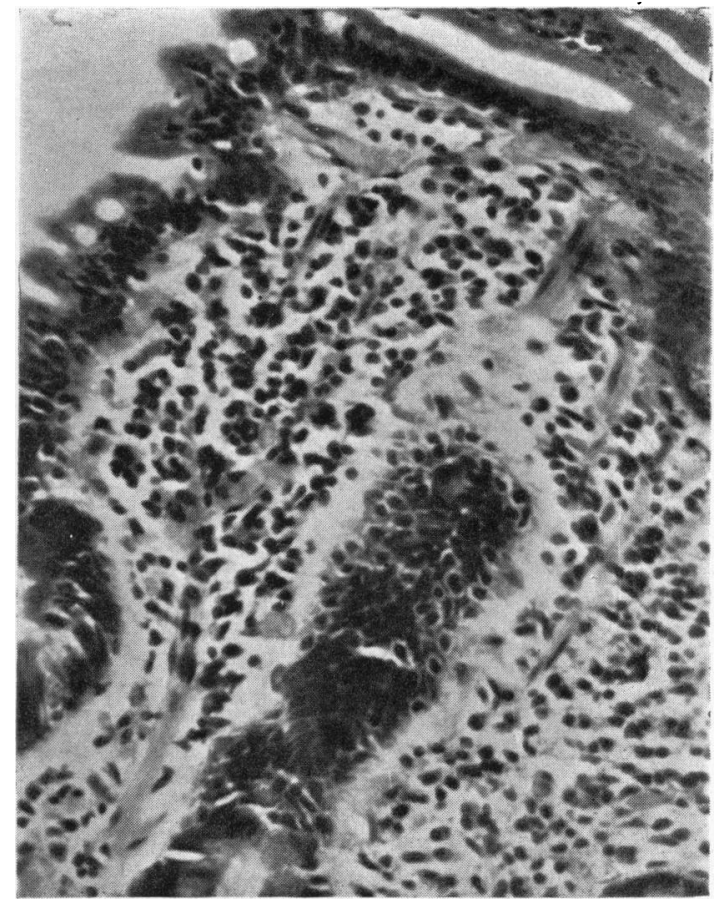

FIG. 5.-Jejunal biopsy while on gluten-free diet $((a) \times 75$, (b) $\times 330$.) Note round cell infiltration without oedema.

By this time, the results of electron microscopy of the intestinal biopsy material had come through, which showed dilated spaces, possibly lymphatic (Fig. 7), similar to the findings of Waldmann et al. (1961).

The patient was sent home on a normal diet. He has remained perfectly well, without any symptoms. When last seen (September 1963), his height was $5 \mathrm{ft}$. $0 \frac{5}{8}$ in. $(153 \mathrm{~cm}$.) (just below 50th percentile) and weight $47 \cdot 3$ kg. (just above 50th percentile). The serum proteins were 5.6 g. $/ 100 \mathrm{ml}$. and plasma s.g. 1023.

Case 3. G.B., a girl born in 1956, had swelling of both feet at birth.

At the age of 1 month, serum albumin was $2 \cdot 1 \mathrm{~g}$. $/ 100$ $\mathrm{ml}$. and globulin $1.7 \mathrm{~g} . / 100 \mathrm{ml}$. The oedema rapidly disappeared without treatment, and by 2 months she was quite well. At the age of 2 years, serum albumin was $3.9 \mathrm{~g} . / 100 \mathrm{ml}$. and globulin $1.6 \mathrm{~g} . / 100 \mathrm{ml}$. Since then she has been in every way a normal child. For the past two years, she has had repeated attacks of tonsillitis. She was admitted to the Metabolic Ward at the same time as her brother to establish whether or not she had the same disease. She had no symptoms and there were no abnormal physical signs except for chronically infected tonsils. Her height was $4 \mathrm{ft}$. $0 \frac{1}{4}$ in. $(122.5 \mathrm{~cm}$.) and weight $24.3 \mathrm{~kg}$., both on the 90 th percentile. The total serum protein was $4.4 \mathrm{~g} . / 100 \mathrm{ml}$., plasma specific gravity 1020-21, and electrophoresis showed a low albumin and $\gamma$-globulin. 


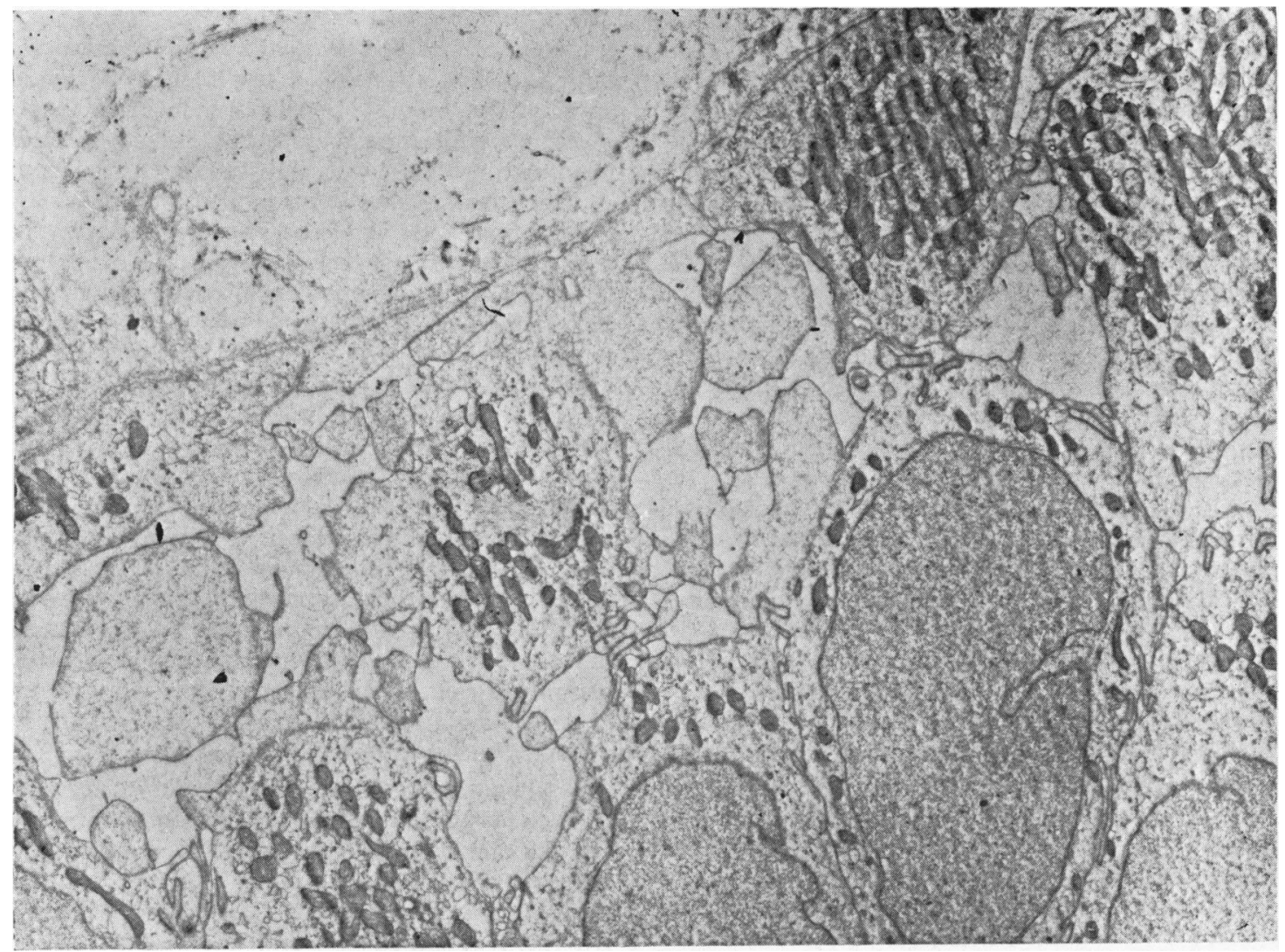

FIG. 7.-Electron microscopy of jejunal mucosa showing dilated lymphatic spaces.

The most important other investigations, shown in Table II, confirmed the leak of macromolecules, of less severity than was found in her brother at the time of his ascites. There was no steatorrhoea, but the abnormal mucosal appearances on barium meal were very similar. Unfortunately, an attempt to obtain a small intestinal biopsy was unsuccessful, and it was not thought justifiable to do this under a general anaesthetic.

Results of other investigations were: sodium 144, potassium $4.5 \mathrm{mEq} /$ litre, urea $20 \mathrm{mg} . / 100 \mathrm{ml}$, haemoglobin $13.6 \mathrm{~g}$. $/ 100 \mathrm{ml}$., WBC 8,600 with normal differential, sedimentation rate $7 \mathrm{~mm}$./hr., prothrombin concentration $100 \%$; urinary excretion of formiminoglutamic acid after histidine load (Dr. J. P. Knowles) was slightly higher than normal ( $3 \mathrm{mg}$./hr., normal $1 \mathrm{mg}$./ $\mathrm{hr}$ ); calcium $8.6 \mathrm{mg}$. $/ 100 \mathrm{ml}$., phosphorus $4.6 \mathrm{mg}$./100 $\mathrm{ml}$., and alkaline phosphatase 15 units.

After completion of the investigations, she was transferred to the Royal Ear Hospital where Miss W. J. Wadge carried out a tonsillectomy. When last seen (September 1963) she was $4 \mathrm{ft} .4 \frac{1}{8}$ in. $(132 \mathrm{~cm}$.) tall, weighed $30.4 \mathrm{~kg}$., and had total serum proteins $4.8 \mathrm{~g}$./ $100 \mathrm{ml}$., and plasma s.g. 1021-1022.

\section{Discussion}

Three members of this sibship had neonatal oedema due to hypoproteinaemia, two were shown to have an increased protein exudation, and one to have a structural abnormality of the small bowel. It is overwhelmingly probable that all three are examples of the same disease, and would have shown the same histology and other findings.

Reviewing the published material up to the end of 1959, Gordon (1960) could find no evidence of a genetic basis for PLE. However, Cottom, London, and Wilson (1961) reported neonatal hypoproteinaemia in two sibs, in one of which PLE was demonstrated. Furthermore, in retrospect, the two sibs reported by Corbeel, Malbrain, and Devisscher (1954) probably suffered from the same condition. In addition to these three families, the propositus of the family originally described by Homburger and Petermann (1949) has recently been reinvestigated and shown to have dilated intestinal lymphatics and 
PLE (T. A. Waldmann, 1963, personal communication).

We have found published records of 49 cases ${ }^{\star}$ in which hypoproteinaemic oedema had begun in childhood. In addition to the seven cases in the three families just cited, the onset was at birth in four other single cases (Lévesque, Coffin, Duplay, Dehelly, Brizard, Seboucq, and Renaut, 1953; Dvořák, Kubovy, Zázvorka, and Hons, 1954; Dooren, van Gelderen, and Vink, 1961; and T. A. Waldmann, 1963, personal communication). This association between onset at birth and positive family history supports the suggestion of Waldmann et al. (1961) that such cases constitute a distinct subgroup in which the abnormality is genetically determined.

The nosological status of most of the cases beginning in later life is obscure. In some the disease is short lived and is followed by complete recovery (Waldmann et al., 1961). Some of the cases of transient hypoproteinaemia in children in the earlier reports probably likewwise had temporary PLE possibly precipitated by an attack of gastro-enteritis. A similar occurrence has been reported in an adult (Jeffries, Holman, and Sleisenger, 1962). It is unlikely that genetic factors are concerned in this group. Complete recovery, however, cannot be established on clinical grounds alone, as witness the third case in the present family. Most patients with intestinal lymphangiectasis have unremitting oedema from the time of presentation, but two have been observed who had had previous episodes of transient oedema (T. A. Waldmann, 1963, personal communication). Fluctuation in the severity of the PLE and steatorrhoea despite a constant anatomical abnormality (as was shown in our propositus) has not previously been described, though Donaldson and Holt (1963) reported an equally inexplicable recovery after a seven-year illness in a patient with an apparently normal small bowel. It is possible that some of the apparent recoveries recorded likewise do not reflect any change in the underlying disease. The importance of genetic factors in cases of intestinal lymphangiectasis not presenting in infancy is uncertain, though the previously cited family of Homburger and Petermann (1949) shows that not all the familial cases present at or soon after birth.

There are some other features of the familial neonatal cases which are worthy of note. There is evidently a very great variation in the severity of the disease, from a transient and mild illness with complete clinical recovery ( 1 case), to a severe progressive

$\star$ References supplied on request. illness with eventual death ( 3 cases). This may be a matter of bias in selection, since very mild cases without a family history are less likely to be investigated. The severity of the disease in infancy is partly dependent on the susceptibility to infection associated with the very low levels of total or $\gamma$ globulin, which have been found in 5 neonatal cases and 2 others. In later life, the $\gamma$-globulin level is higher, though still below normal. This is well shown by our propositus who, after almost succumbing to infection, has subsequently been quite normal in this respect. The statement by Jeffries et al. (1962), that hypo- $\gamma$-globulinaemia in patients with PLE does not increase susceptibility to infection, was based on analysis of adult cases only and does not apply to infants. Another interesting point is the temporary aminoaciduria which has been found in 3 cases. This could be due to absorption of amino acids derived from breakdown of protein in the gut, in excess of the capacity of the liver to incorporate them in newly synthesized protein. This explanation is supported by the finding of a raised plasma $\alpha$ amino nitrogen, during the first illness of our propositus (Bound and Hackett, 1953), and in one other patient (Stoelinga, Van Munster, and Slooff, 1963).

Many patients with PLE also have steatorrhoea. Jarnum (1961) first commented on the frequency of this association which has been described in many different conditions. In some of these there is a recognizable lesion in the small bowel, such as lymphangiectasis (Waldmann et al., 1961), Crohns disease (Vesin, Troupel, Acar, Bismuth, Renault, and Cattan, 1960a), granulomatous jejunitis (Holman, Nickel, and Sleisenger, 1959), jejunal diverticulosis (Dawson et al., 1961), or the villous atrophy of sprue (Parkins, 1960; Rubini, Sheehy, Meroney, and Louro 1961). In other cases the small bowel is apparently normal, but there is some predisposing or associated condition such as gastro-enteritis (Jeffries et al., 1962) post-gastrectomy syndrome (Jarnum, 1961), or carcinoma of the bronchus (Turner and Williams, 1962). Occasionally PLE and steatorrhoea are found without any other pathological or clinical association (Simpkiss and Sheldon, 1962; Donaldson and Holt, 1963). In some of these conditions the steatorrhoea is principally due to intestinal malabsorption, but there is no convincing evidence for this in most patients with intestinal lymphangiectasis. One case with a flat glucose tolerance test has been reported (Espiner and Beaven, 1962), and a low xylose absorption was found in one case of familial neonatal hypoproteinaemia (Cottom et al., 1961). Malabsorption of vitamin B12 and folic acid has been found in one case by Mistilis, Skyring, and Stephen (1965). The serum calcium may be reduc- 
ed out of proportion to the fall in serum albumin, and in 3 cases frank tetany has occurred (Jeffries et al., 1962; Stoelinga et al., 1963; Mistilis et al., 1965). Tetany was also noted in 4 fatal cases of idiopathic hypoproteinaemia in childhood (Debre, Royer, Lestradet, and Reiser, 1954; Iversen, 1960), but unfortunately it is not possible to make a more exact diagnosis in these cases. Rickets has been described in 2 cases of PLE and steatorrhoea in childhood (Young, Levin, Fowler, and Miles, 1959; Stoelinga et al., 1963), but intestinal biopsy was not performed in either. In all these cases the disturbances of calcium metabolism could have been consequences of steatorrhoea per se, without invoking any abnormality of intestinal transport (Parfitt, 1965). The most reasonable theory, first put forward by Jarnum (1961), is that the steatorrhoea is due to exudation of fat from the gut wall at the same site as the exudation of protein (Cottom et al., 1961). This mechanism is supported by the finding of chylous fluid containing high molecular weight fatty acids in duodenal juice (Stoelinga et al., 1963) and by persistence of steatorrhoea on a fat free diet (Mistilis et al., 1965). Perhaps the term 'exudative enteropathy' should be retained (or revived) to describe this situation (Parfitt, 1965). If the site of exudation is localized, resection of diseased bowel may be followed by disappearance of both hypoproteinaemia and steatorrhoea (Holman et al., 1959). The exudation may be from both surfaces of the gut wall-into the peritoneal cavity as well as into the gut lumen (Jarnum and Petersen, 1961). The relationship of the exudative process to lymphatic obstruction has been studied in a patient with constrictive pericarditis (Petersen and Hastrup, 1963); after cannulation of the thoracic duct, delayed appearance of ${ }^{131}$ I-labelled oleic acid after oral administration was shown. At necropsy, dilatation of intestinal lymphatics was found: they were regarded as a consequence of chronic venous congestion. In other cases, lymphatic obstruction and dilatation may be a consequence of local inflammatory disease of the bowel (Holman et al., 1959), whereas in the present family, the lymphatic dilatation is presumably secondary to some congenital abnormality. This abnormality may be confined to the bowel, or may be associated with evidence of lymphatic obstruction in the limbs (Pomerantz and Waldmann, 1963; Mistilis et al., 1965). Although interest in the intestinal lymphatic system in relation to exudative enteropathy has only recently developed, a lesion remarkably similar to intestinal lymphangiectasis was described many years ago in a patient with postgastrectomy steatorrhoea (Vaux, 1943).
The findings of villous atrophy in our propositus, an abnormality not described in most patients with lymphangiectasis (Waldmann et al., 1961), suggested that he might have gluten enteropathy, even though this could not have been the cause of the first episode of oedema which occurred six months before exposure to gluten. Forshaw (1957) described a patient with hypoproteinaemic oedema who was cured by a gluten-free diet, and the same author subsequently noted a similar occurrence after partial gastrectomy (Forshaw, 1958). London, Bamforth, and Creamer (1961) reported a patient in whom hypoproteinaemic oedema developed suddenly in middle age; the patient had subtotal villous atrophy and recovered completely on a gluten-free diet. Although our patient appeared to recover on a gluten-free diet, reintroduction of gluten had no clinical or biochemical effect, so that the diet merely coincided with a spontaneous clinical remission. Jeffries et al. (1962) reported a very similar case, in which there was a much stronger clinical resemblance to coeliac disease. Investigations revealed PLE and steatorrhoea with a normal xylose absorption. Intestinal biopsy showed dilated lymphatic spaces and partial villous atrophy (as in our case). A gluten-free diet was given for 5 months without effect. Thus the villous atrophy was not due to gluten enteropathy in either case in which it was associated with lymphangiectasis, and its significance remains obscure. A gluten-free diet has been tried in 4 other cases of hypoproteinaemic oedema with PLE (Cottom et al., 1961; Young et al., 1959; Simpkiss and Sheldon, 1962; Stoelinga et al., 1963), and in none was any convincing benefit observed. In one other case, a girl of 14 , a gluten-free diet has been followed by remission (Vesin, Troupel, Acar, Renault, Desbuquois, and Cattan, 1960b). After 3 months the patient was given $100 \mathrm{~g}$. bread and experienced mild abdominal colic and diarrhoea. Unfortunately gluten sensitivity was not further documented and intestinal biopsy was not performed. The evidence is not sufficient to decide whether the patient had a spontaneous clinical remission (as in our case), or had gluten enteropathy presenting with hypoproteinaemic oedema and PLE (as in the adult cases mentioned earlier), or represents a different condition altogether (as suggested by the authors).

\section{Summary}

A child with neonatal oedema who was previously reported as a case of idiopathic hypoproteinaemia was reinvestigated 10 years later and shown to have protein-losing enteropathy and steatorrhoea, and an abnormal small bowel histology with dilated 
lymphatic spaces and partial villous atrophy. The patient's symptom-free sister was also shown to have protein-losing enteropathy.

The relationship of this syndrome to intestinal malabsorption and gluten enteropathy is discussed.

This work would not have been possible without the great help and advice of Dr. Margot Shiner, who performed the intestinal biopsies, and Dr. A. M. Dawson, who performed the PVP tests. The author's thanks are also due to Professor C. E. Dent for help and encouragement and permission to publish, to Miss Christine Harper for the analytical work related to the metabolic balance study, to Dr. D. A. W. Edwards for assistance with the preparation of the illustrations, to Mr. A. Bligh for the photomicrographs, to Dr. J. F. Soothill for the $\gamma$-globulin estimation, and to Miss Jan Bayada and Mrs. Kathleen Gates for secretarial assistance.

\section{REFERENCES}

Albright, F., Bartter, F. C., and Forbes, A. P. (1949). The fate of human serum albumen administered intravenously to a patient with idiopathic hypoalbuminemia and hypoglobulinemia. Trans. Ass. Amer. Phycns, 62, 204.

Bound, J. P., and Hackett, W. R. (1953). Idiopathic hypoproteinaemic oedema and amino-aciduria in an infant. Arch. Dis. Childh., 28, 104.

Citrin, Y., Sterling, K., and Halsted, J. A. (1957). The mechanism of hypoproteinemia associated with giant hypertrophy of the gastric mucosa. New Engl. F. Med., 257, 906.

Corbeel, L., Malbrain, H., and Devisscher, M. (1954). L'hypoprotéinémie essentielle chez l'enfant. Acta paediat. belg., 8, 337.

Cottom, D. G., London, D. R., and Wilson, B. D. R. (1961). Neonatal oedema due to exudative enteropathy. Lancet, 2, 1009.

Dawson, A. M., Williams, R., and Williams, H. S. (1961). Faecal P.V.P. excretion in hypoalbuminaemia and gastrointestinal disease. Brit. med. F., 2, 667.

Debre, R., Royer, P., Lestradet, H., and Reiser, D. (1954). L'hypoprotéinémie idiopathique de l'enfant. Sem. Hôp. Paris, 29, 1899.

Donaldson, R. M., Jr., and Holt, P. R. (1963). Idiopathic proteinlosing enteropathy in an adult, with apparently complete recovery. Amer. F. Med., 34, 572.

Dooren, L. J., Gelderen, H. H. van, and Vink, C. L. J. (1961). Exudative enteropathy. Acta paediat. (Uppsala), 50, 249.

Dvořák, J., Kubovy, A., Zázvorka, Z., and Hons, J. (1954). Ein Fall von idiopathischer Hypoalbuminämie mit Aminoacidurie beim Säugling. Helv. paediat. Acta, 9, 258.

Espiner, E. A., and Beaven, D. W. (1962). Protein-losing enteropathy: a case of anasarca with hypoproteinaemia. Aust. Ann. Med., 11, 205.

Forshaw, J. W. B. (1957). Idiopathic steatorrhoea associated with severe hypoproteinaemia. Lancet, 2, 720.

- (1958). Hypoproteinaemia after partial gastrectomy corrected by gluten-free diet. Brit. med. F., 2, 1020.

Gordon, R. S. (1959). Exudative enteropathy. Abnormal permeability of the gastrointestinal tract demonstrable with labelled polyvinylpyrrolidone. Lancet, 1, 325.

- (1960). Hereditary hypoproteinemias and other plasma protein abnormalities. In The Metabolic Basis of Inherited Disease, ed. J. B. Stanbury, J. B. Wyngaarden, and D. S. Fredrickson, p. 1379. McGraw-Hill, New York.

Holman, H., Nickel, W. F., Jr., and Sleisenger, M. H. (1959). Hypoproteinemia antedating intestinal lesions, and possibly due to excessive serum protein loss into the intestine. Amer. F. Med., 27, 963.
Homburger, F., and Petermann, M. L. (1949). Studies in hypoproteinemia II. Familial idiopathic dysproteinemia. Blood, 4, 1085.

Iversen, T. O. (1960). A case of idiopathic hypoproteinaemia. Acta paediat. (Uppsala), 49, 82.

Jarnum, S. (1961). The ${ }^{131}$ I- polyvinylpyrrolidone (131I-PVP) test in gastrointestinal protein loss. Scand. F. clin. Lab. Invest., 13, 447.

, and Petersen, V. P. (1961). Protein-losing enteropathy. Lancet, 1, 417.

Jeffries, G. H., Holman, H. R., and Sleisenger, M. H. (1962). Plasma proteins and the gastrointestinal tract. New Engl. $\mathcal{F}$. Med., 266, 652.

Kinsell, L. W., Margen, S., Tarver, H., Frantz, J. McB., Flanagan, E. K., Hutchin, M. E., Michaels, G. D., and McCallie, D. P. (1950). Studies in methionine metabolism. III. The fate of intravenously administered $S^{35}$-labelled-methionine in normal adult males, in patients with chronic hepatic disease, 'idiopathic' hypoproteinemia and Cushing's syndrome. F. clin. Invest., 29, 238.

Knowles, J. P. (1962). Excretion of formimino-glutamic acid in steatorrhoea. Gut, 3, 42.

Lancet (1959). Protein-losing gastroenteropathy. 1, 351.

Lévesque, J., Coffin, R., Duplay, Dehelly, Brizard, Seboucq, and Renaut, Mlle. (1953). Hypoprotéinémie essentielle avec agammaglobulinémie chez une enfant à la naissance. Arch. franc. Pédiat., 10, 879.

London, D. R., Bamforth, J., and Creamer, B. (1961). Steatorrhoea presenting with gastrointestinal protein loss. Lancet, $2,18$.

Mistilis, S. P., Skyring, A. P., and Stephen, D. D. (1965). Intestinal lymphangiectasia. ibid, 1, 77 .

O'Meallie, L. P. (1963). Protein-losing gastroenteropathy. Amer. f. med. Sci., 245, 109.

Parfitt, A. M. (1965). The semantics of steatorrhoea. Med. f. Aust., 1, 112.

Parkins, R. A. (1960). Protein-losing enteropathy in the sprue syndrome. Lancet, 2, 1366.

Petersen, V. P., and Hastrup, J. (1963). Protein-losing enteropathy in constrictive pericarditis. Acta med. scand., 173, 401.

Pomerantz, M., and Waldmann, T. A. (1963). Systemic lymphatic abnormalities associated with gastrointestinal protein loss secondary to intestinal lymphangiectasia. Gastroenterology, 45, 703.

Rubini, M. E., Sheehy, T. W., Meroney, W. H., and Louro, J. (1961). Exudative enteropathy. II. Observations in tropical sprue. f. Lab. clin. Med., 58, 902.

Schwartz, M., and Jarnum, S. (1959). Gastrointestinal protein loss in idiopathic (hypercatabolic) hypoproteinaemia. Lancet, 1, 327.

Simpkiss, M., and Sheldon, W. (1962). Enteropathic hypoproteinaemia. Arch. Dis. Childh., 37, 68.

Stoelinga, G. B. A., Van Munster, P. J. J., and Slooff, J. P. (1963) Chylous effusions into the intestine in a patient with proteinlosing enteropathy. Pediatrics, 31, 1011.

Turner, P., and Williams, R. (1962). Unexplained steatorrhoea in the syndome of hyponatraemia and carcinoma of bronchus. Brit. med. F., 1, 287.

Vesin, P., Troupel, S., Acar, J., Bismuth, V., Renault, H., and Cattan, R. (1960a). Iléo-colite de Crohn. Étude du métabolisme intestinal par la trioléine-131 I et le PVP-131I. Bull. Soc. Méd. Hôp Paris, 76, 410.

_ -1, , Renault, H., Desbuquois, G., and Cattan, R. (1960b). Entéropathie avec perte de proteines et stéatorrhée. Etude par le PVP-131I et la trioléine-131I. Action du régime sans gluten. ibid., 76, 261.

Waldmann, T. A. (1961). Gastrointestinal protein loss demonstrated by ${ }^{31}$-Cr-labelled albumin. Lancet, $2,121$.

, Steinfeld, J. L., Dutcher, T. F., Davidson, J. D., and Gordon, R. S., Jr. (1961). The role of the gastrointestinal system in 'idiopathic hypoproteinemia'. Gastroenterology, 41, 197.

Vaux, D. M. (1943). Chyladenectasis with steatorrhoea. F. Path. Bact., 55, 93.

Young, W. F., Levin, B., Fowler, J. F., and Miles, J. M. (1959). Gastrointestinal protein loss in severe malabsorption complicated by idiopathic (hypercatabolic) hypoproteinaemia. Lancet, $2,85$. 